\title{
Inverted Colonic Diverticula Cases
}

\author{
Arzu Tiftikçi ${ }^{1}$ (D) , Emrehan Parlak² (D) , Bircan Boğaª ${ }^{2}$ (DD , \\ Serpil Yılmaz ${ }^{3}$ (D) , Bahattin Çiçek ${ }^{1}$ (D)
}

\footnotetext{
${ }^{1}$ Acıbadem Mehmet Ali Aydınlar University Medical Faculty, Gastroenterology Department, Istanbul/Turkey

${ }^{2}$ Acıbadem Mehmet Ali Aydınlar University Medical Faculty, Istanbul/ Turkey

${ }^{3}$ Nişantaşı Pathology Group, Istanbul/ Turkey
}

Arzu TifTikçi, Prof. Dr.

Emrehan PARLAK

Bircan BOĞA

Serpil YILMAZ, Uzm. Dr.

Bahattin Çiç̧EK, Prof. Dr.

\section{Correspondence: Arzu Tiftikçi} Acıbadem Mehmet Ali Aydıllar University Medical Faculty, Gastroenterology Department, Istanbul/Turkey

Phone: +905323562217

E-mail: arzutiftikci@gmail.com

Received

Accepted

$$
\text { : } 28 \text { February } 2021
$$

\section{ABSTRACT}

Colonic diverticula are outpouchings of mucosa and submucosa through the large intestine wall. Inverted colonic diverticula can be confused with colonic adenoma. It is important to differentiate them. Here we report two cases of inverted diverticula that seem to like adenomas.

Keywords: Diverticula, polyp, inversion

\section{Ters dönmüş kolonik divertikül: İki Olgu Sunumu}

ÖZET

Kolonik divertikula kolon duvarında mukoza ve submukozanın içe çökmesi şeklinde görülür. Ters dönmüş divertikül, kolonik adenomla karışabilir. Biz burada adenoma benzeyen iki ters dönmüş kolonik divertikül olgusu sunuyoruz.

Anahtar Sözcükler: Ters dönmüş kolonik divertikül, adenom, polipektomi

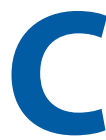

olonic diverticula are outpouchings of mucosa and submucosa through the large intestine wall $(1,2)$ accompanied by structural changes like muscular thickening, mucosal folding and taenia coli elastosis (2). They are classified as pseudodiverticula (1) unlike the appendix which is a true diverticulum that also includes the muscular layer. Focal weaknesses in the colonic wall such as areas where arterial vasa recta and nerves meet the circular muscular layer or areas adjacent to taenia coli have tendency to form diverticula (3). Although diverticula are mostly asymptomatic and are found incidentally on colonoscopy, some of them give symptoms and have potentially dangerous complications such as infection, perforation, obstruction, and bleeding (1). Even intussusception have been reported as a complication of diverticula (4). 
Inverted colonic diverticula (ICD) are observed in nearly $\% 0.7$ of the population (5) and are mostly seen in sigmoid colon. In colonoscopy it is hard to differentiate ICD from neoplastic polypoid structures. Resection of an ICD assumed to be a neoplastic polyp can lead to serious complications. These include perforation of the colonic wall and peritonitis due to the discharge of the colonic content (6). Therefore, it is crucial to distinguish ICD from neoplastic polyps. Some approaches exist to help diagnose ICD during colonoscopy. However, there are few studies in literature showing both macroscopic and microscopic characteristic features of ICD. For this reason, our study aims to report the colonoscopic and histopathologic findings of two of our patients diagnosed with ICD.

\section{Data}

\section{Case 1}

A 49-year-old man without any gastrointestinal complaints presented for his first screening colonoscopy. His past medical history included nephrolithiasis, a previous cholecystectomy and routine usage of a beta blocker for hypertension. The patient was a heavy smoker and drinker. Endoscopic inspection revealed an irregular zone (3 $\mathrm{cm} \times 5 \mathrm{~cm}$ in diameter) in the sigmoid colon which, by inspection, showed properties of an eroded polyp or an ICD (figure 1). After being elevated by saline injection, an endoloop was applied and the lesion was partially removed with snare cautery (figure 2 ). The remaining zone was marked with Indian Ink. Colonoscopy was continued until the terminal ileum and revealed multiple diverticula throughout the colon. The patient did not have a history of complications (such as bleeding, inflammation and perforation) related to widely distributed diverticula. Small polyps were detected in the cecum and were removed with biopsy forceps. As visualized $15 \mathrm{~cm}$ of terminal ileum and rectum seemed normal. The patient tolerated the procedure well without any complaints. Histopathological evaluation of sample revealed reactive changes in colonic mucosa characterized by crypt hyperplasia and increased goblet cell density. The lesion didn't have characteristics of typical colonic polyps and morphological findings supporting mucosal changes seen in colonic diverticular disease (figure 3).

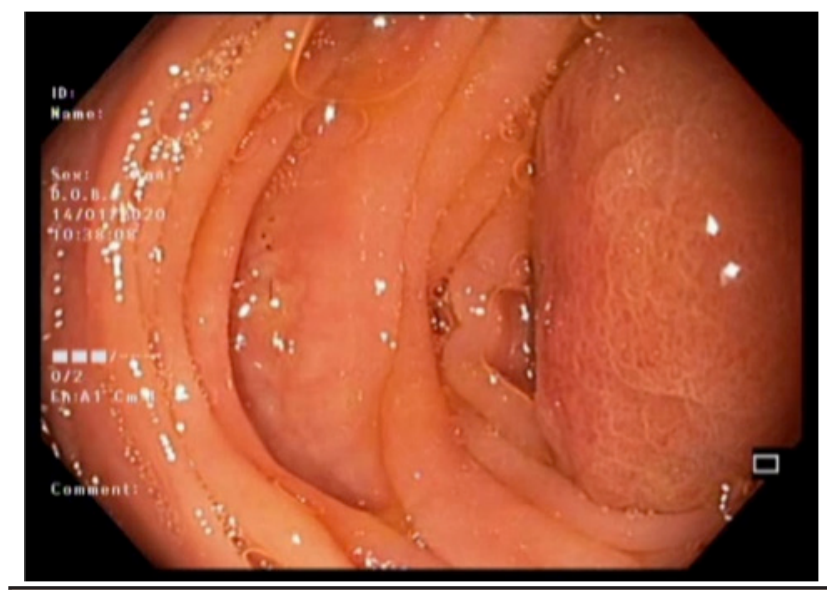

Figure 1: Endoscopic apparance of inverted diverticulum that looks like sesille adenomatous polyp

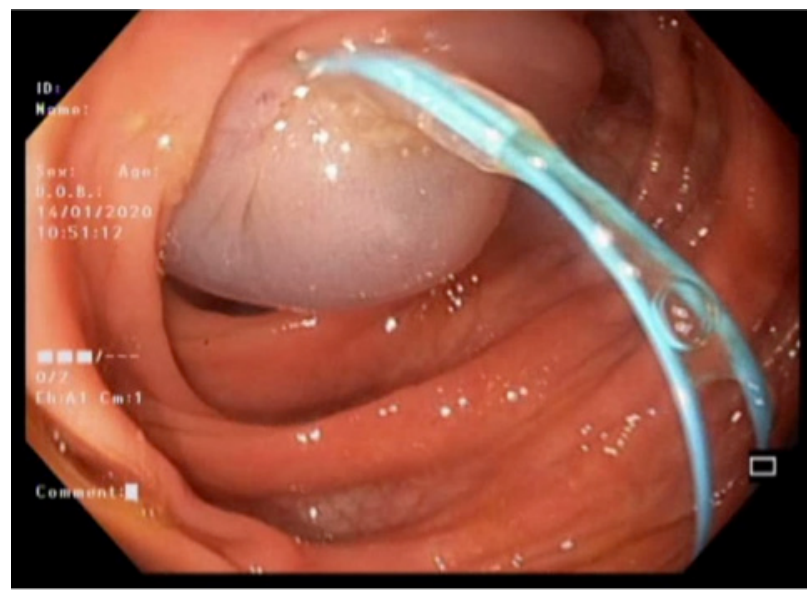

Figure 2: Endoscopic apperance of snare polypectomy after insertion of endoloop

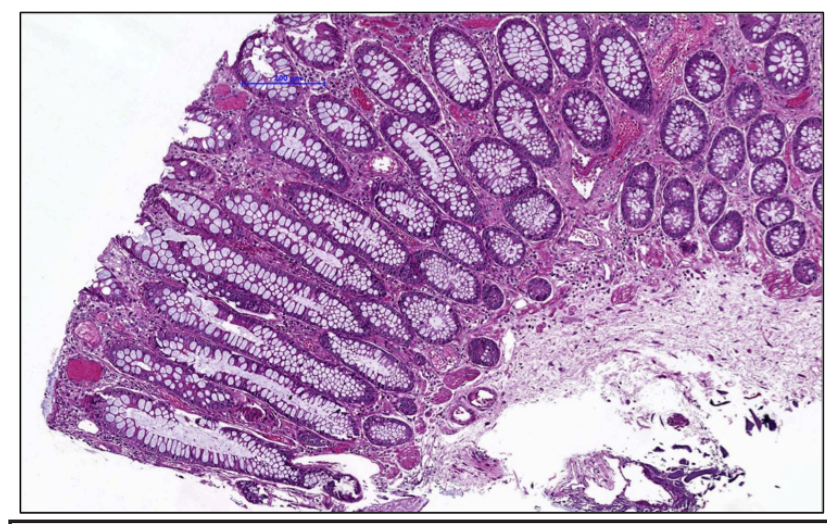

Figure 3: Crypt hyperplasia and increased goblet cell density (hematoxylin and eosin, $x 7,48$ ) 
Case 2

A 51-year-old man presented for his routine screening colonoscopy. His past medical history included right hemicolectomy due to frequent diverticulitis and also previous tubular adenoma removal. The patient was a heavy smoker and drinker. Endoscopic examination revealed a hyperemic lesion ( $2 \mathrm{~cm} \times 3 \mathrm{~cm}$ in diameter) possibly related to infection or incarceration of colonic mucosa (Figure 4). The undetermined lesion seemed to be compatible with an ICD on gross view thus multiple biopsies were taken from it. The remaining sigmoid colon included an adenomatous sessile polyp and also a diverticular opening. Rectum included a sessile polyp. The rest of the colon seemed to be normal until the anastomosis. The patient tolerated the procedure well without any complaints.There were 5 biopsy samples between $1 \mathrm{~mm}$. and $5 \mathrm{~mm}$. in diameter. At histopathological examination colonic mucosa with mildly active chronic inflammatory infiltration, crypt hyperplasia, architectural distortion and dilatation, serration of superficial and crypt epithelium and myofibroblastic proliferation surrounding the crypts was seen. The lesion had properties of a mucosal prolapse. Morphological findings supported mucosal changes seen in colonic diverticular disease (figure 5).

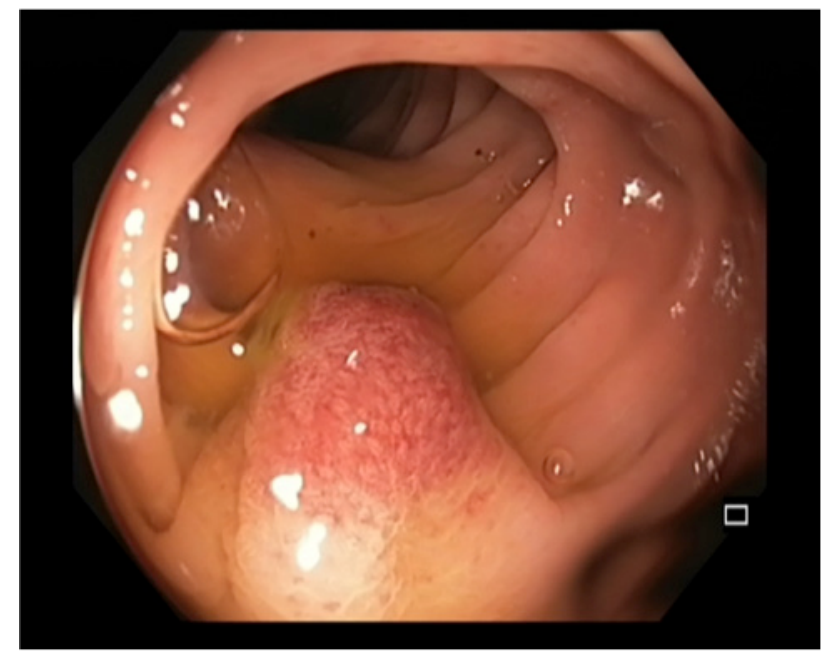

Figure 4: Endoscopic apparance of inverted diverticulum that looks like mucosal jamming or adenomatous polyp

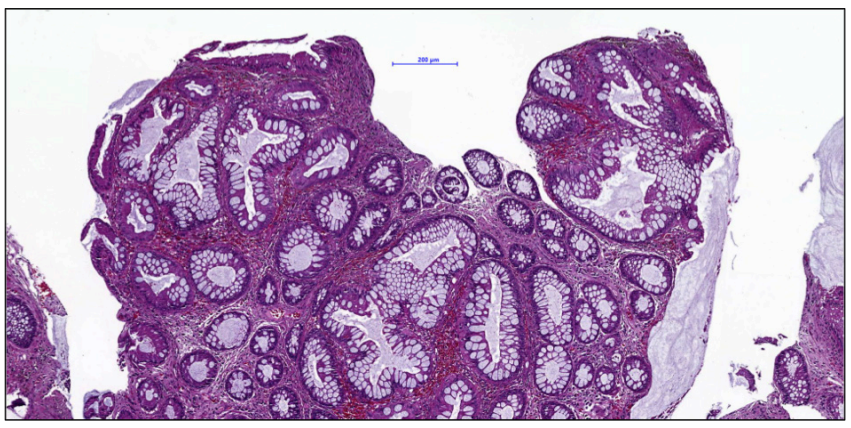

Figure 5: Crypt hyperplasia, architectural distortion and dilatation, serration of superficial and crypt epithelium and myofibroblastic proliferation surrounding the crypts. (hematoxylin and eosin, $x 7,57$ )

\section{Discussion}

Colonic diverticula are commonly encountered lesions on colonoscopy. Although most of the diverticula have typical apperance, rarely they can be inverted and resemble colonic hyperplastic or adenomatous polyps. Resection of these ICD may lead to colonic perforation and even ICD, itself may lead to serious complications such as intussusception (4) Endoloop assisted biopsies of such lesions could be helpful in terms of exact diagnosis. Various studies described some criteria to differentiate ICD from typical colonic polyps. One study suggested polypoid lesions seen in diverticular segments of the colon have a high possibility of being an ICD if they are voluminous, soft, congestive and broad-stalked (7). ICD's larger than $2 \mathrm{~cm}$ are subject to be misdiagnosed as a pedunculated polyp compared to smaller lesions (8). It is crucial to distinguish ICD from neoplastic polyps. Some approaches exist to help diagnose ICD during colonoscopy, such as attempting to revert the lesion with forceps (9), air insufflation, checking water jet deformation sign (10), radiating pillow sign or looking for concentric pale rings surrounding the lesion referred as Aurora rings (11). Both cases in our study had their ICD located in sigmoid colon with other typical diverticular and polypoid structures nearby. They were encountered incidentally on routine colonoscopy. Our patients had different past medical histories however both of them did not report any complaints or complications specifically related to their ICD. If these lesions were accepted as typical colonic polyps and the possibility of an ICD was not considered during colonoscopy, resection of them would lead to life threatening serious complications such as perforation which can be seen in one out of 1400 of all colonoscopy procedures (12). This complication occurs possibly more often in misdiagnosed ICD resections. 
Taking biopsies or large resection after endoloop insertion can be an option to differentiate ICD from adenomatous polyp histopathologically. However this approach may need a second colonoscopy in true polipoid cases.

Newer technological approaches that help to identify such undetermined lesions are being devised in order to minimize the complication risk and increase the diagnostic accuracy during colonoscopy. However, most of these magnifying based technologies are limited to differentiate malignant polyps from nonneoplastic ones. Future studies should focus on discovering technologies and techniques to maximize the diagnostic accuracy during colonoscopy for patients' safety and speed recovery.

\section{References}

1. Travis AC. Diverticular disease of the colon. In: Greenberger NJ, Blumberg RS, Burakoff R. eds. Current diagnosis and treatment Gastroenterology, Hepatology and Endoscopy. Cham: MC GrawHill Education.. A lange medical book: publishing 2016. p 274-88

2. Gearhart S. Diverticular disease and common anorectal disorders. In: Longo DL, Fauci AS eds. Harrison's Gastroenterology and Hepatology. Cham: MC Graw-Hill Education. publishing 2013. P 212-26

3. Matrana MR and Margolin DA. Epidemiology and pathophysiology of diverticular disease. Clin Colon Rectal Surg. 2009; 22 (3):141-8

4. Zhang B, Wang J, Li X, et al. Intussusception Caused by an Inverted Colonic Diverticulum: A Case Report. J Med Case Rep. 2018; 27;12(1):114. DOI:10.1186/s13256-018-1652-9

5. Merino RC, Kinney T, Santander R, et al. Inverted Colonic Diverticulum:An infrequent and dangerous endoscopic finding. Gastrointesti Endosc. 2005 ; 61(5) AB257: W1120

6. Yusuf SI and Grant C. Inverted colonic diverticulum: a rare finding in a common condition? Gastrointest Endosc. 2000; 52(1): 111-5.

7. Dumas $\mathrm{O}$, Jouffre $\mathrm{C}$, Desportes $\mathrm{R}$ et al. Inverted sigmoid diverticulum: a misleading polyp. Gastrointest Endosc. 1991;37(5): 587-8.

8. Paoluzi OA, Tosti C, Andrei F. et al. Look out before polypectomy in patients with diverticular disease--A case of a large inverted diverticulum of the colon resembling a pedunculated polyp. Can J Gastroenterol. 2010;24(1):61-3

9. Adioui $\mathrm{T}$ and Seddik $\mathrm{H}$. Inverted colonic diverticulum. Ann Gastroenterol. 2014; 27(4):411

10. Cappel MS. The water jet deformation sign: a novel provocative colonoscopic maneuver to help diagnose an inverted colonic diverticulum. South Med J. 2009; 102(3):295-8

11. Share MD, Avila A, Dry SM, et al. Aurora rings:a novel endoscopic finding to distinguish inverted colonic diverticula from colon polyps. Gastrointest Endosc. 2013; 77(2): 308-12

12. Iqbal CW, Cullinane DC, Schiller $\mathrm{HJ}$, et al. Surgical management and outcomes of 165 colonoscopic perforations from a single institution. Arch Surg. 2008;143(7): 701-6 